\title{
(S)-Garner aldehyde derived Baylis-Hillman adduct: A potential substrate for the synthesis of D-lyxo phytosphinosine analogue
}

\author{
GULSHAN KUMAR, AMANPREET KAUR and VASUNDHARA SINGH* \\ Department of Applied Sciences (Chemistry), PEC University of Technology, Chandigarh 160 012, India \\ e-mail: vasun7@yahoo.co.in
}

MS received 3 February 2014; revised 19 April 2014; accepted 25 April 2014

\begin{abstract}
A short, facile and efficient synthesis of D-lyxo-phytosphingosine analogue has been achieved. The key steps involved are the Baylis-Hillman reaction of (S)-Garner aldehyde with methyl acrylate to obtain the corresponding adduct as the potential substrate, to which was added decylmagnesium bromide to obtain the E-trisubstituted alkene followed by $\mathrm{OsO}_{4} / \mathrm{NMO}$ mediated dihydroxylation gave the desired D-lyxophytosphingosine analogue intermediate diol which on acid hydrolysis resulted in the formation of the target molecule in good yield.
\end{abstract}

Keywords. Baylis-Hillman acetates; decylmagnesium bromide; (S)-garner aldehyde; D-lyxophytosphingosine; $\mathrm{OsO}_{4} / \mathrm{NMO}$ dihydroxylation.

\section{Introduction}

The Baylis-Hillman ${ }^{1,2}$ reaction is an important atom economical carbon-carbon bond forming reaction in organic synthesis which involves the coupling of activated vinylic system and an electrophile under the catalytic influence of tertiary amines to afford multifunctional adducts. Aldehydes are the main substrate for this reaction and among them the chiral $\alpha$-amino aldehydes $^{3}$ are of special interest due to the synthetic utility of the resulting adducts which have the multifunctional $\alpha$-methylene- $\beta$-hydroxy- $\gamma$-amino acid moiety present in them.

Acetates of Baylis-Hillman ${ }^{1,4}$ have been exploited as potential intermediates for the stereoselective synthesis of a variety of multifunctional molecules and natural products. Moreover, the trisubstituted alkene moiety found abundantly in various naturally occurring bioactive molecules including important antibiotics and pheromones is a key intermediate for the stereoselective synthesis of a variety of multifunctional compounds. ${ }^{5}$ The various reported methodologies employed for stereoselective synthesis of trisubstituted alkenes from Baylis-Hillman acetates mainly includes reactions with Grignard reagent, ${ }^{6}$ Pd-catalyzed cross-coupling reaction, ${ }^{7}$ reaction of trialkylindium reagent, ${ }^{8} \mathrm{Zn}$ mediated reaction of alkyl halides in aqueous medium[5e] and Friedel-Crafts reaction. ${ }^{9}$ Roy et al. ${ }^{10}$ have recently reported the synthesis of

\footnotetext{
*For correspondence
}

trisubstituted alkenes via titanocene(III) chloride. The reaction is mediated by radically induced addition of activated bromo compounds to acetates of Baylis-Hillman adduct.

Sphingolipids are essential membrane components of all eukaryotic cells and are involved in various cellular processes such as the regulation of cell growth, adhesion, differentiation, neuronal repair and signal transduction. ${ }^{11}$ The basic structure of a sphingolipid is composed of an aminodiol and triol backbone called sphingoid base, a polar head group (sugar, phosphate, sulphate) and a fatty acyl chain linked to amino group via amide bond. The most abundantly found sphingoid bases in nature include D-erythro-sphingosine, dihydrosphingosine and phytosphingosine.

Phytosphingosines (figure 1), are 2-amino-1,3,4 triol bases which are important naturally occurring bioactive sphingolipids found abundantly in plants, microorganisms and in many mammalian tissues. ${ }^{12}$ Phytosphingosines are known to regulate cellular growth ${ }^{13}$ and mediates the heat stress signals of yeast cells. ${ }^{14}$ They also act as metabolic precursors for many lipid mediators. ${ }^{15}$ Beside natural phytosphingosines, their analogues exhibit antifungal ${ }^{16}$ and other important physiological activities such as high tumor inhibitory potency. ${ }^{17}$ The glycosylated derivative of phytosphingosine, KRN700 is known to exhibit potent immunostimulatory properties capable of activating natural killer $\mathrm{T}$ (NKT) cells to produce a spectrum of cytokines. ${ }^{18}$ Due to the biological significance of phytosphingosines and their analogues, various methodologies for 


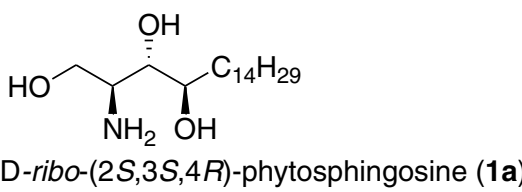

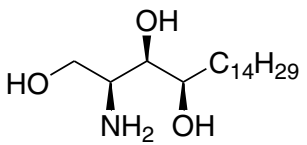

D-xylo-(2S,3R,4R)-phytosphingosine (1c)

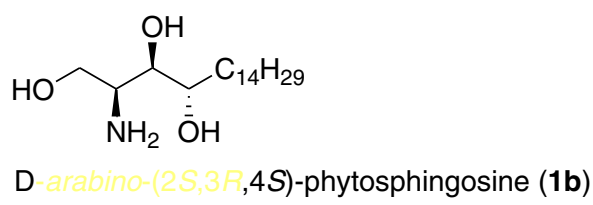

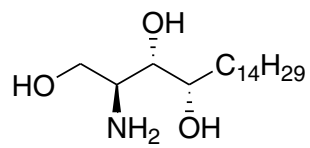

D-lyxo-(2S,3S,4S)-phytosphingosine (1d)<smiles>N[C@@H](CO)[C@H](O)[C@](O)(CCCCO)C(=O)O</smiles>

D-Iyxo-(2R,3S,4S)-phytosphingosine analogue (1e)

Figure 1. Phytosphingosines and D-lyxo-phytosphingosine analogue.

stereoselective and efficient synthesis have been developed and described in literature. ${ }^{19,20}$

The configurationally stable Garner aldehyde ${ }^{21}$ has received considerable attention as an important chiral synthon for the stereoselective synthesis of phytosphingosines and their derivatives ${ }^{20 c, e, 22}$ due to its inherent 2-amino-1,3-diol subunit which is the backbone of sphingolipids. The $(S)$-Garner aldehyde-methyl acrylate 3a derived Baylis-Hillman adduct was earlier reported by Drewes $e t$ al. $^{23}$ as a potential intermediate for the synthesis of sphingolipid analogue. However, no work has been reported in this direction in literature for its further transformation to sphingolipids or their derivatives.

\section{Experimental}

\subsection{General methods}

Melting points are uncorrected. ${ }^{1} \mathrm{H}$ and ${ }^{13} \mathrm{C}$ NMR spectra were recorded on a Bruker Avance II $400 \mathrm{MHz}$ spectrometer at 400 and $100 \mathrm{MHz}$, respectively. IR spectra were recorded using a Perkin-Elmer model RX 1 FT-IR spectrometer. Mass spectra were recorded on Waters Micromass q-Tof Micro spectrometer. Elemental analyses were performed using automatic Perkin Elmer $2400 \mathrm{CHN}$ elemental analyzer. Optical rotations (in degrees) were recorded on Autopol-III polarimeter. The Baylis-Hillman reaction was sonicated in an ultrasonic cleaner $(40 \pm 5 \mathrm{kHz})$. The column chromatography was performed using silica gel (Merck, 60-120 mesh), and the flash chromatography was performed using silica gel (Merck, 230-400 mesh) by eluting with solvent indicated. All reactions were carried out using oven-dried glassware. All solvents were dried prior to use, as reported in literature.

\subsection{Procedure for synthesis of (S)-tert-butyl 4-[(R)-2-(methoxycarbonyl)-1-acetoxyallyl]-2,2- dimethylloxazolidine-3-carboxylate (4)}

To a stirred solution of Baylis-Hillman adduct 3a $(3.0 \mathrm{~g}$, $9.52 \mathrm{mmol}$ ), pyridine (1.5 g, $19.0 \mathrm{mmol})$, DMAP (cat.) in dry $\mathrm{CH}_{2} \mathrm{Cl}_{2}(40 \mathrm{~mL})$ at $0^{\circ} \mathrm{C}$, acetic anhydride $(1.95 \mathrm{~g}$, $19.0 \mathrm{mmol})$ in dry $\mathrm{CH}_{2} \mathrm{Cl}_{2}(15 \mathrm{~mL})$ was added dropwise. The mixture was stirred at $0^{\circ} \mathrm{C}$ for $4 \mathrm{~h}$ till complete consumption of starting Baylis-Hillman adduct occurred as monitored by TLC. The mixture was poured into icecold water $(25 \mathrm{~mL})$ and extracted with $\mathrm{CH}_{2} \mathrm{Cl}_{2}(3 \mathrm{x}$ $30 \mathrm{~mL}$ ). The combined organic layers were washed successively with cold aqueous $5 \% \mathrm{HCl}(30 \mathrm{~mL})$, water $(30 \mathrm{~mL})$, saturated aqueous $\mathrm{NaHCO}_{3}(30 \mathrm{~mL})$, brine (30 mL) and dried over $\mathrm{Na}_{2} \mathrm{SO}_{4}$. After filtration, the solvent was removed under reduced pressure and the crude product was purified by column chromatography over silica gel (hexane: EtOAc, 89:11) to afford $4(2.17 \mathrm{~g}, 64 \%)$ a white solid as shown inbreak scheme 1 .

${ }^{1} \mathrm{H}$ NMR $\left(400 \mathrm{MHz}, \mathrm{CDCl}_{3}\right): \delta 1.41-1.62(\mathrm{~m}, 15 \mathrm{H})$, $2.14(\mathrm{~s}, 3 \mathrm{H}), 3.76(\mathrm{~s}, 3 \mathrm{H}), 3.78-3.86(\mathrm{~m}, 1 \mathrm{H}), 3.95-$ $3.98(\mathrm{~m}, 1 \mathrm{H}), 4.23-4.40(\mathrm{~m}, 1 \mathrm{H}), 5.86(\mathrm{~s}, 1 \mathrm{H}), 5.93$ $(\mathrm{s}, 0.43 \mathrm{H}), 6.16(\mathrm{~s}, 0.57 \mathrm{H}), 6.40(\mathrm{~s}, 1 \mathrm{H}) ;{ }^{13} \mathrm{C} \mathrm{NMR}$ $\left(100 \mathrm{MHz}, \mathrm{CDCl}_{3}\right): \delta 23.2,25.9,28.3,30.8,52.0,57.6$, $62.9,64.5,70.1,80.6,94.9,127.3,137.3,151.8,165.0$, 169.2; ESIMS m/z $380.5\left(\mathrm{M}^{+}+\mathrm{Na}\right)$; Anal. Calcd. for $\mathrm{C}_{17} \mathrm{H}_{27} \mathrm{NO}_{7}$ : C, 57.12; H, 7.61; N, 3.91. Found: C, $57.05 ; \mathrm{H}, 7.55 ; \mathrm{N}, 3.89$. 
<smiles>CC1(C)OC[C@H](C=O)N1C(=O)O</smiles>

2<smiles>C=C(C(=O)OC)[C@@H](O)[C@H]1COC(C)(C)N1C(=O)O</smiles>

$3 a$<smiles>C=C(COC(=O)OC(C)(C)C)[C@@H](O)[C@H]1COC(C)(C)N1C(=O)O</smiles>

$3 b$<smiles>C=C(C(C)=O)[C@@H](OC(C)=O)[C@@H]1COC(C)(C)N1C(C)=O</smiles>

4

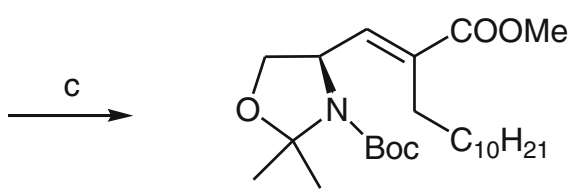

5
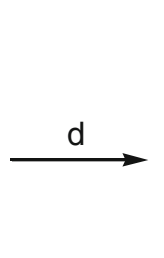

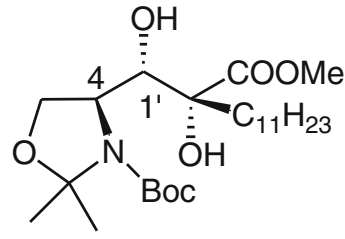

$6 a$

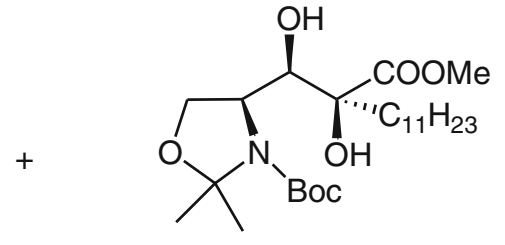

$77: 23$

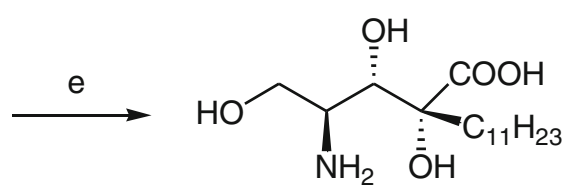

$1 e$

Scheme 1. Reagents and conditions: (a) DABCO, )))), methy acrylate 40 h, 73\%, (b) Acetic anhydride, Pyridine, DMAP (cat.), $\mathrm{CH}_{2} \mathrm{Cl}_{2}, 0^{\circ} \mathrm{C}, 4 \mathrm{~h}, 64 \%$, (c) $\mathrm{C}_{10} \mathrm{H}_{21} \mathrm{MgBr}$, THF, reflux, $5 \mathrm{~h}, 56 \%$, (d) $\mathrm{OsO}_{4}, \mathrm{NMO}, \mathrm{Me}_{2} \mathrm{CO}, \mathrm{H}_{2} \mathrm{O}, \mathrm{rt}, 48 \mathrm{~h}, 65 \%$, (e) Synthesis of D-lyxo-(2R,3S,4S)-phytosphingosine (1e).

\subsection{Procedure for synthesis of $(R)$-tert-butyl 4-[(E)-2-(methoxycarbonyl)tridec-1-enyl]-2,2- dimethyloxazolidine-3-carboxylate (5)}

To the stirred, freshly prepared Grignard reagent, [from decyl bromide (1.63 g. $7.36 \mathrm{mmol})$ and activated magnesium turning $(0.179 \mathrm{~g}, 7.36 \mathrm{mmol})]$ in dry THF $(10 \mathrm{~mL})$ under nitrogen was added dropwise a solution of the acetate $4(1.75 \mathrm{~g}, 4.90 \mathrm{mmol})$ in dry THF $(10 \mathrm{~mL})$ at $0^{\circ} \mathrm{C}$. After addition was completed, the reaction mixture was refluxed for $5 \mathrm{~h}$ until TLC indicated no further change in composition of the reaction mixture. The reaction mixture was cooled to $0^{\circ} \mathrm{C}$ and saturated aqueous $\mathrm{NH}_{4} \mathrm{Cl}$ solution was carefully added. The mixture was extracted with $\mathrm{Et}_{2} \mathrm{O}(4 \times 25 \mathrm{~mL})$, dried over $\mathrm{Na}_{2} \mathrm{SO}_{4}$, filtered and concentrated under reduced pressure. Purification by column chromatography over silica gel (hexane:EtOAc, 94:6) afforded 5 (1.20 g, 56\%) as colorless oil as shown in scheme 1 .

${ }^{1} \mathbf{H}$ NMR $\left(400 \mathrm{MHz}, \mathrm{CDCl}_{3}\right): \delta 0.88(\mathrm{t}, J=6.6 \mathrm{~Hz}$, $3 \mathrm{H}), 1.25-1.29(\mathrm{~m}, 18 \mathrm{H}), 1.41-1.62(\mathrm{~m}, 15 \mathrm{H}), 2.32-$ $2.39(\mathrm{~m}, 2 \mathrm{H}), 3.68-3.71$ (dd, $J=8.8,3.7 \mathrm{~Hz}, 1 \mathrm{H}), 3.75$ (s, 3H), 4.10-4.13 (dd, $J=8.6,6.8 \mathrm{~Hz}, 1 \mathrm{H}), 4.58-$ $4.78(\mathrm{~m}, 1 \mathrm{H}), 6.60-6.63(\mathrm{~d}, J=8.7 \mathrm{~Hz}, 1 \mathrm{H}) ;{ }^{13} \mathbf{C}$ NMR $\left(100 \mathrm{MHz}, \mathrm{CDCl}_{3}\right): \delta 14.1,22.6,23.9,26.1,27.3,28.7$, $29.2,30.2,51.8,55.1,68.0,80.1,94.5,132.9,141.0$,
151.7, 167.9; ESIMS $m / z 462.3\left(\mathrm{M}^{+}+\mathrm{Na}\right)$. Anal. Calcd. for $\mathrm{C}_{25} \mathrm{H}_{45} \mathrm{NO}_{5}$ : C, 68.30; H, 10.31; N, 3.18. Found: C, 68.23; H, 10.24; N, 3.15.

\subsection{Procedure for synthesis of (S)-tert-butyl 4-} [(1S,2R)-2-(methoxycarbonyl)-1,2-dihydroxytridecyl]2,2-dimethyloxazolidine-3-carboxylate (6a)

To a stirred solution of $\mathrm{OsO}_{4}(4 \%$ aq. solution, $0.11 \mathrm{~mL}$, $0.017 \mathrm{mmol})$ and NMO (1.12 g, $5.13 \mathrm{mmol})$ in acetone: $\mathrm{H}_{2} \mathrm{O}(8: 1,15 \mathrm{~mL})$ was added alkene $5(0.750 \mathrm{~g}$, $1.7 \mathrm{mmol})$ at $0^{\circ} \mathrm{C}$. The mixture was stirred at room temperature for $48 \mathrm{~h}$ until TLC indicated complete consumption of starting material. The reaction was quenched with saturated aqueous $\mathrm{Na}_{2} \mathrm{SO}_{3}(10 \mathrm{~mL})$. The acetone was evaporated under reduced pressure. The aqueous mixture was extracted with EtOAc $(4 \times 10 \mathrm{~mL})$, dried over $\mathrm{Na}_{2} \mathrm{SO}_{4}$, filtered and concentrated under reduced pressure to afford mixture of diols 6a:6b in 73:27 diastereomeric ratio as observed by ${ }^{1} \mathrm{H}$ NMR spectrum analysis of the crude mixture. Purification by column chromatography over silica gel (hexane:EtOAc, 80:20) afforded pure $6 \mathbf{a}(0.507 \mathrm{~g}, 65 \%)$ as a colorless oil as shown in scheme 1. 
${ }^{1} \mathbf{H}$ NMR $\left(400 \mathrm{MHz}, \mathrm{CDCl}_{3}\right): \delta 0.87(\mathrm{t}, J=6.6 \mathrm{~Hz}$, $3 \mathrm{H}), 1.23-1.29$ (m, 18H), 1.41-1.65 (m, 16H),61.67$1.89(\mathrm{~m}, 1 \mathrm{H}) 2.57$ (br s, 1H), 3.50-3.65 (br s, 1H), $3.82(\mathrm{~s}, 3 \mathrm{H}), 3.90-3.94(\mathrm{dd}, J=9.7,6.4 \mathrm{~Hz}, 1 \mathrm{H})$, 4.15-4.23 (m, 2H), 4.51-4.53 (d, $J=9.8 \mathrm{~Hz}, 1 \mathrm{H})$; ${ }^{13}$ C NMR (100 MHz, d $\mathrm{d}_{6}$-DMSO): $\delta$ 14.1, 23.2, 26.7, 28.4, 29.4, 31.9, 35.1, 53.0, 57.9, 63.7, 74.2, 75.3, 80.6, 93.5, 152.5, 175.5; ESIMS $m / z$ 496.4 $\left(\mathrm{M}^{+}+\mathrm{Na}\right)$. Anal. Calcd. for $\mathrm{C}_{25} \mathrm{H}_{47} \mathrm{NO}_{7}: \mathrm{C}, 63.39 ; \mathrm{H}, 10.00 ; \mathrm{N}, 2.95$. Found: C, 63.34; H, 9.94; N, 2.92 .

\subsection{Procedure for synthesis of tert-butyl (2S,4R)-4-(methoxycarbonyl)-1,3,4- trihydroxypentadecan-2-ylcarbamate (7)}

To a solution of $\mathbf{6 a}(0.110 \mathrm{~g}, 0.23 \mathrm{mmol})$ in $\mathrm{MeOH}$ $(5 \mathrm{~mL})$ was added Amberlyst $15(0.155 \mathrm{~g})$ and the resulting heterogeneous mixture was stirred for $48 \mathrm{~h}$ at room temperature till consumption of starting material occured as monitered by TLC. The mixture was passed through a small pad of celite and $\mathrm{MeOH}$ was evaporated under reduced pressure to afford the crude residue. Purification by coloumn chromatography over silica gel $\left(\mathrm{CHCl}_{3}: \mathrm{MeOH}, 9: 1\right)$ afforded $7(0.072 \mathrm{~g}, 71 \%)$ as a colorless viscous oil as shown in scheme 2.

${ }^{1} \mathbf{H}$ NMR $\left(400 \mathrm{MHz}, \mathrm{CDCl}_{3}\right): \delta 0.88(\mathrm{t}, J=6.8 \mathrm{~Hz}$, $3 \mathrm{H}), 1.23-1.45(\mathrm{~m}, 27 \mathrm{H}), 1.60-1.70(\mathrm{~m}, 1 \mathrm{H}), 1.75-$ $1.79(\mathrm{~m}, 1 \mathrm{H}), 3.76-3.80(\mathrm{~m}, 1 \mathrm{H}), 3.82(\mathrm{~s}, 3 \mathrm{H}), 3.90$ $3.91(\mathrm{~m}, 1 \mathrm{H}), 4.02-4.03(\mathrm{~m}, 2 \mathrm{H}), 5.39-5.41(\mathrm{~d}, J=$ $8.4 \mathrm{~Hz}, 1 \mathrm{H},-\mathrm{NH}) ;{ }^{13} \mathbf{C}$ NMR $\left(100 \mathrm{MHz}, \mathrm{CDCl}_{3}\right): \delta$ 14.1, 22.6, 23.4, 28.3, 29.3, 29.4, 29.5, 29.6, 34.7, 51,6, 53.2, 60.4, 63.0, 79.9, 80.3, 155.6, 175.4.Anal. Calcd. for $\mathrm{C}_{22} \mathrm{H}_{43} \mathrm{NO}_{7}: \mathrm{C}, 60.97 ; \mathrm{H}, 9.93 ; \mathrm{N}, 3.2$. Found: $\mathrm{C}$, $60.89 ; \mathrm{H}, 9.90 ; \mathrm{N}, 3.15$.

2.6 Procedure for synthesis of tert-butyl (4S,5S)-4[(R)-1-(methoxycarbonyl)-1-hydroxydodecyl]-2,2dimethyl-1,3-dioxan-5-ylcarbamate (8)

To a solution of $7(0.045 \mathrm{~g}, 0.10 \mathrm{mmol})$ and DMP (108 mg, $1.0 \mathrm{mmol})$ in dry $\mathrm{CH}_{2} \mathrm{Cl}_{2}(5 \mathrm{~mL})$ was added
PPTS $(0.026 \mathrm{~g}, 0.10 \mathrm{mmol})$. The mixture was stirred for $48 \mathrm{~h}$ at room temperature and concentrated under reduced pressure. Purification by column chromatography over sillca gel (hexane:EtOAC, 84:16) afforded pure $8(0.030,62 \%)$ as a white solid as shown in scheme 2.

${ }^{1} \mathbf{H}$ NMR $\left(400 \mathrm{MHz}, \mathrm{CDCl}_{3}\right): \delta 0.87(\mathrm{t}, J=$ $6.8 \mathrm{~Hz}, 3 \mathrm{H}), 1.25-1.50(\mathrm{~m}, 33 \mathrm{H}), 1.59-1.68(\mathrm{~m}, 1 \mathrm{H})$, $1.73-1.78(\mathrm{~m}, 1 \mathrm{H}), 3.59-3.62(\mathrm{~m}, 1 \mathrm{H}), 3.78(\mathrm{~s}, 3 \mathrm{H})$, 3.83-3.87 (m, 1H), 4.05-4.08 (m, 1H), 4.99-5.01 (d, $\left.J_{4.5}=9.9 \mathrm{~Hz}, 1 \mathrm{H}\right), 5.25(\mathrm{~s}, 1 \mathrm{H}, \mathrm{NH}), 6.0\left(\mathrm{bs}, 1 \mathrm{H}, \mathrm{OH}, \mathrm{D}_{2} \mathrm{O}\right.$ exchangeable); ${ }^{13} \mathbf{C}$ NMR $\left(100 \mathrm{MHz}, \mathrm{CDCl}_{3}\right): \delta 14.1$, 21.0, 22.8, 26.6, 28.5, 29.4, 29.7, 30.0, 30.9, 31.9, 52.5, 53.2, 63.5, 78.4, 79.5, 82.2, 99.3, 155.7, 172.6. Anal. Calcd. for $\mathrm{C}_{25} \mathrm{H}_{47} \mathrm{NO}_{7}$ : C, 63.42; H, 9.93; N, 2.93 . Found: C, 63.40; H, 9.88; N, 2.9.

\subsection{Procedure for synthesis of \\ D-lyxo-(2R,3S,4S)-phytosphingosine (1e)}

A solution of $6 \mathbf{a}(0.080 \mathrm{~g}, 0.17 \mathrm{mmol})$ in $1 \mathrm{~N} \mathrm{HCl}$ $(6 \mathrm{~mL})$ and dioxane $(6 \mathrm{~mL})$ was heated at $100^{\circ} \mathrm{C}$ with stirring for $1 \mathrm{~h}$ under nitrogen atmosphere. The reaction mixture was cooled to room temperature and neutralized with aqueous $1 \mathrm{~N} \mathrm{NaOH}(6 \mathrm{~mL})$. The mixture was extracted with EtOAc $(5 \times 10 \mathrm{~mL})$. The combined organic layers were washed with brine $(10 \mathrm{~mL})$ and dried over $\mathrm{Na}_{2} \mathrm{SO}_{4}$. Removal of solvent under reduced pressure followed by purification with flash chromatography over a short column of silica gel $\left(\mathrm{CHCl}_{3}: \mathrm{MeOH}, 5: 1\right)$ afforded D-lyxo-phtosphingosine analogue 1e $(0.039,72 \%)$ as a white solid as shown in scheme 1.

${ }^{1}$ H NMR (400 MHz, d ${ }_{6}$-DMSO): $\delta 0.87(\mathrm{t}, J=$ $6.8 \mathrm{~Hz}, 3 \mathrm{H}), 1.25-1.39(\mathrm{~m}, 17 \mathrm{H}), 1.46-1.57(\mathrm{~m}, 2 \mathrm{H})$, 1.67-1.73 (m, 1H), 3.36-3.41 (m, 1H), 3.69-3.74 (m, $1 \mathrm{H}), 3.98-4.01(\mathrm{~m}, 1 \mathrm{H}), 4.09-4.10(\mathrm{~d}, J=2.0 \mathrm{~Hz}$, $1 \mathrm{H}$ ), 4.43 (br s, $3 \mathrm{H},-\mathrm{OH}), 7.80-8.06$ (br s, $2 \mathrm{H},-\mathrm{NH}_{2}$ ); ${ }^{13}$ C NMR (100 MHz, d ${ }_{6}$-DMSO): $\delta 14.3,22.5,23.5$, 29.6, 31.7, 35.3, 54.8, 58.5, 73.7, 79.7, 175.7. ESIMS $m / z 320.5\left(\mathrm{M}^{+}+1\right), 302.5\left(\mathrm{M}^{+}-\mathrm{OH}\right)$. Anal. Calcd.

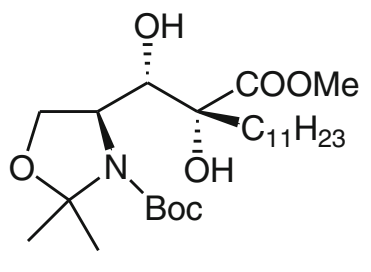

$6 a$

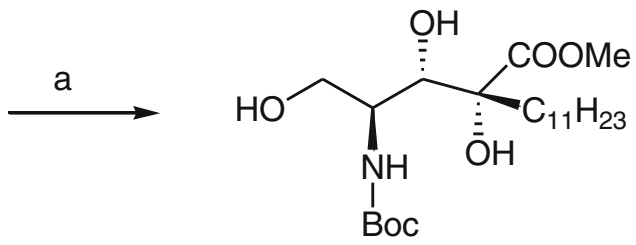

7

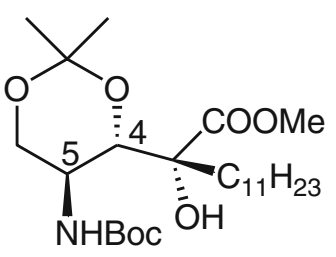

$8 \quad \mathrm{~J}_{4,5}=9.9 \mathrm{~Hz}$

Scheme 2. Reagents and conditions: (a) Amberlyst 15, MeOH, rt, 48 h, 71\%, (b) DMP, PPTS, $\mathrm{CH}_{2} \mathrm{Cl}_{2}, \mathrm{rt}, 48$ h, $62 \%$. 
for $\mathrm{C}_{16} \mathrm{H}_{33} \mathrm{NO}_{5}$ : C, 73.48; $\mathrm{H}, 9.47 ; \mathrm{N}, 3.05$. Found: C, 73.39; H, 9.41; N, 3.03 .

\section{Results and Discussion}

In continuation to our work ${ }^{24}$ towards the synthesis of sphingolipids and their analogues and synthesis of a lactone ceramide, ${ }^{24 \mathrm{~b}}$ we have established the first, efficient and general methodology exploiting the multifunctional molecule $(S)$-Garner aldehyde-methyl acrylate derived Baylis-Hillman adduct 3a for the synthesis of D-lyxo-phytosphingosine analogue 1e via a sequence of reactions (scheme 1).

The Baylis-Hillman reaction ${ }^{3 g}$ of $(S)$-Garner aldehyde 2 with methyl acrylate in the presence of DABCO under ultrasound sonication afforded a 6:1 mixture of adducts $\mathbf{3 a}$ and $\mathbf{3 b}$. The major adduct3a was separated by column chromatography over silica gel in 73\% yield as a colorless oil. The anti stereochemistry has been assigned to $\mathbf{3 a}$ by comparison with spectroscopic data and optical rotation value reported in literature. ${ }^{3 \mathrm{~h}, 23}$ The anti stereochemistry of the major adduct may be rationalized on the basis of FelkinAhn open-chain model. ${ }^{25}$ The adduct $3 \mathbf{a}$ was converted to the corresponding acetate 4 by treating with acetic anhydride in the presence of pyridine and catalytic DMAP under standard conditions in 64\% isolated yield as a white solid. Refluxing a mixture of acetate 4 with decylmagnesium bromide ${ }^{6}$ in dry THF for $5 \mathrm{~h}$ under nitrogen atmosphere provided the trisubstituted alkene 5 with $E$-stereochemistry in $56 \%$ isolated yield as a colourless oil. The $E$-stereochemistry was assigned on the basis of ${ }^{1} \mathrm{H}$ NMR spectral analysis showing $\beta$-vinylic proton cis to the ester group appeared as a doublet, $J=8.3 \mathrm{~Hz}$ at $\delta 6.60-6.63$ which is the characteristic peak for such Roy et al. ${ }^{10}$ have recently reported the synthesis of trisubstituted alkenes via titanocene(III) chloride. The reaction is mediated by radically induced addition of activated bromo compounds to acetates of Baylis-Hillman adduct. ${ }^{5 e, 6}$ The alkene 5 was screened for diastereoselective dihydroxylation with $\mathrm{AD}$ mix- $\alpha / \beta^{22 \mathrm{e}}$ and $\mathrm{OsO}_{4} / \mathrm{NMO}$ dihydroxylating reagents under standard reaction conditions. No dihydroxylated product was obtained using AD mix$\alpha$ or $\beta$ as dihydroxylating reagent with almost complete recovery of unreacted alkene $\mathbf{5}$. This may be due to steric hindrance around the double bond of alkene 5 which obstructs the approach of the bulky oxidation group to the double bond. However, the $\mathrm{OsO}_{4} / \mathrm{NMO}$ catalyzed dihydroxylation of $\mathbf{5}$ proceeded quantitatively to yield a diastereomeric mixture of diols $\mathbf{6 a}$ and $\mathbf{6 b}$ in 77:23 ratio as observed by ${ }^{1} \mathrm{H}$ NMR spectrum analysis of the crude mixture. The major diastereomer $6 \mathbf{6}$ was separated by column chromatography over silica gel in $65 \%$ yield as colourless oil. The anti stereochemistry of the major diol 6a for C (4) and C (1) was established by converting it to the corresponding six membered O,O-acetonide $\mathbf{8}$ in two steps (scheme 2) ) $^{26,27}$ and its ${ }^{1} \mathrm{H}$ NMR analysis.

Firstly, the oxazolidine group was removed by treatment with an acidic resin (Amberlyst 15) in $\mathrm{MeOH}$ to afford 7 in $71 \%$ isolated yield as a viscous oil followed by acetalization using 2,2-dimethoxy propane and PPTS in $\mathrm{CH}_{2} \mathrm{Cl}_{2}$ to give the acetonide 8 in $62 \%$ yield as a white solid. The vicinal coupling constant of $9.9 \mathrm{~Hz}$ between $\mathrm{H}-5$ and $\mathrm{H}-4$ of acetonide 8 confirmed the anti stereochemistry by ${ }^{1} \mathrm{H}$ NMR spectral analysis.

Deprotection of diol $\mathbf{6 a}$ under acidic conditions in $1 \mathrm{~N} \mathrm{HCl/dioxane}{ }^{28}$ provided crude D-lyxophytosphingosine analogue which on subsequent purification by flash column chromatography over a short column of silica gel afforded pure D-lyxophytosphingosine analogue $\mathbf{1 e}$ in $72 \%$ yield as a white solid. All the compounds were characterized by ${ }^{1} \mathrm{H}$, ${ }^{13} \mathrm{C}-\mathrm{NMR}$ and mass spectroscopy (see supplementary information).

\section{Conclusions}

We have synthesized D-lyxo-phytosphingosine analogue 1e by exploiting the Baylis-Hillman adduct $\mathbf{3 a}$ derived acetate 4 via decylmagneisum bromide addition for the stereospecfic synthesis of $E$-trisubstituted alkene 5 and $\mathrm{OsO}_{4} / \mathrm{NMO}$ mediated dihydroxylation as the key steps. To the best of our knowledge this is the first report for the synthesis of D-lyxo-phytosphingosine analogue 1e starting from (S)-Garner aldehyde-methyl acrylate derived Baylis-Hillman adduct 3a. The same methodology can also be applied to the synthesis of other phytosphingosine stereoisomers and their analogues.

\section{Supplementary Information}

The complete spectral data of the title compound $\mathbf{1 e}$ has been included in the supplementary information (see www.ias.ac.in/chemsci).

\section{Acknowledgements}

The authors GK and AK are thankful to CSIR, New Delhi and Technical Education Quality Improvement Programme (TEQIP-II), PEC University of Technology for providing financial assistance. We are grateful to Sophisticated Analytical Instrumentation Facility (Mr. 
Avtar Singh for Nuclear Magnetic Resonance), Panjab University, Chandigarh for analytical facilities.

\section{References}

1. (a) Ciganek E, 1997 Org. React. 51 201; (b) Basavaiah D, Rao P D and Hyma R S 1996 Tetrahedron 52 8001; (c) Kim J N and Lee K Y 2002 Curr. Org. Chem. 6 627; (d) Basavaiah D, Rao A J and Satyanarayana T 2003 Chem. Rev. 103 811; (e) Lee K Y, Gowrisankar S and Kim J N 2005 Bull. Korean Chem. Soc. 26 1481; (f) Basavaiah D, Reddy B S and Badsara S S 2010 Chem. Rev. 1105447

2. (a) Xue S, He L, Han K-Z, Liu Y-K and Guo Q-X 2005 Synlett 8 1247; (b) Calmes M, Akkari R, Barthes N, Escale F and Martinez J 2005 Tetrahedron: Asymmetry 16 2179; (c) Gowrisankar S, Lee H S, Lee K Y, Lee J-E and Kim J N 2007 Tetrahedron Lett. 48 8619; (d) Lee H S, Kim T H and Kim J N 2008 Tetrahedron Lett. 49 1773; (e) Gowrisankar S, Lee H S, Kim J M and Kim J N 2008 Tetrahedron Lett. 491670

3. (a) Ameer F, Drewes S E, Houston-McMillan M S and Kaye P T S 1986 Afr. J. Chem. 39 57; (b) Roos G and Manickum T 1991 Synth. Commum, 21 2269; (c) Manickum T and Roos G H P S 1994 Afr. J. Chem. 47 1; (d) Nayak S P, Thijs L and Zwanenburg 1999 Tetrahedron Lett. 40 981; (e) Almeida B W P and Coelho F 2001 Tetrahedron Lett. 44 937; (f) Krishna P R, Sachwani R and Kannan V 2004 Chem. Commun. 2580; (g) Coelho F, Diaz G, Abella C A M and Almeida W P 2006 Synlett 435; (h) Nakano A, Takahashi K, Ishihara J and Hatakeyama S 2006 Org. Lett. 85357

4. (a) Basavaiah D, Rao P D and Suguna H R 1996 Tetrahedron 52 8001; (b) Drewes S E and Roos G H P 1988 Tetrahedron 44 4653; (c) Basavaiah D, Bakthadoss M and Pandiaraju S 1998 Chem. Commun. 1639; (d) De G P, Silveira C and Coelho F 2005 Tetrahedron Lett. 46 6477

5. (a) Bradshaw J W S, Baker R and Howse P E 1975 Nature 258 230; (b) Rossi R, Carpita A and Messari T 1992 Synth. Commun. 22 603; (c) Herlt A J, Rickards R W, Thomas R D and East P D 1993 J. Chem. Soc., Chem. Commun. 1497; (d) Garson M J 1993 Chem. Rev. 93 1699; (e) Basavaiah D and Hyna R S 1996 Tetrahedron 52 1253; (f) Das B, Banerjee J, Mahender G and Majhi A 2004 Org. Lett. 63349

6. Basavaiah D, Sarma P K S and Bhavani A K D 1994 J. Chem Soc. Chem. Commun. 1091

7. (a) Kabalka G W, Venkataiah B and Dong G 2003 Org. Lett. 5 3803; (b) Kabalka G W, Dong G, Venkataiah B and Chen C 2005 J. Org. Chem. 709207

8. Ranu B C, Chattopadhay K and Jana R 2007 Tetrahedron Lett. 483847

9. (a) Basavaiah D, Pandiraju S and Padmaja K 1996 Synlett 393; (b) Basavaiah D, Krishnamacharyulu M, Hyma R S and Pandiaraju S 1997 Tetrahedron Lett. 382141

10. Mandal S K, Paira M and Roy S C 2008 J. Org. Chem. 733823

11. (a) Riethmuller J, Riehle, Grassme H and Gulbins E 2006 Biochim. Biophys. Acta 1758 2139; (b) Snook C F, Jones J A and Hannun Y A 2006 Biochim. Biophys. Acta 1761927
12. (a) Karlsson K-A and Martensson E 1968 Biochim. Biophys. Acta 152 230; (b) Carter H E and Hirschberg C B 1968 Biochemistry 7 2296; (c) Okabe K, Keeman R W and Schmidt G 1967 Biochim. Biophys. Res. Commmun. 27 319; (d) Wertz P W, Miethke M C, Long S A, Stauss J S and Owning D T 1985 J. Invest. Dertmatol. 84 410; (e) Takamatsu K, Mikami M, Kikuchi K, Nozawa S and Iwamori M 1992 Biochim. Biophys. Acta 1165177

13. Veerman E C I, Valentijn-Benj M, vant't Hof W, Najmi $\mathrm{K}$, van Marle J and Amerongen A V N 2010 Biol. Chem. 39165

14. (a) Jenkins G M, Richards A, Wahl T, Mao C, Obeid L and Hannun Y 1997 J. Biol. Chem. 272 32566; (b) Skrzypek M S, Nagiec M M, Lester R L, Dickson R C 1999 J. Bacteriol 181 1134; (c) Meier K D, Deloche O, Kajiwara K, Funato K and Riezman H 2006 Mol. Biol. Cell 171164

15. Kim M K, Park K S, Lee H, Kim Y D, Yun T and Bae Y S 2007 Exp. Mol. Med. 39185

16. (a) Shier W T, Shier A C J 2000 Toxicol.-Toxin Rev. 19 189; (b) Hirsch S and Kashman Y 1989 Tetrahedron 45 3897

17. (a) Schneiter R 1999 BioEssays 21 1004; (b) Kobayashi E, Motoki K, Yamaguchi Y, Uchida T, Fukushima H and Koezuka Y 1996 Bioorg. Med. Chem. 4615

18. (a) Sharif S, Arreaza G A, Zucker P, Mi Q-S, Sondhi J, Naidenko O V, Kronenberg M, Koezuka Y and Delovitch T L 2001 Nat. Med. 7 1057; (b) Luc Van Kaer 2004 Nat. Rev. Immunol. 531

19. Howell A R and Ndakala A 2002 J. Curr. Org. Chem. 6 365

20. (a) Lu X, Byun H-S and Bittman R 2004 J. Org. Chem. 69 5433; (b) Lu X and Bittman R 2005 Tetrahedron Lett. 46 3165; (c) Lombardo M, Capdevila M G, Pasi F and Trombini C 2006 Org. Lett. 8 3303; (d) Cai Y, Ling C-C and Bundle D R 2006 Org. Biomol. Chem. 4 1140; (e) Jeon J, Shin M, Yoo J W, Oh J S, Bae J G, Jung S H and Kim Y G 2007 Tetrahedron Lett. 48 1105; (f) Abraham E, Candela-Lena J I, Davies S G, Georgiou M, Nicholson R L, Roberts P M, Rusell A J, Smith A D and Thomson J E 2007 Tetrahedron: Asymmetry 18 2510; (g) Chang C-W, Chen Y-N, Adak A K, Lin K-H, Tzou D-L M and Lin C-C 2007 Tetrahedron 63 43101; (h) Kim S W, Lee K C, An G Kim S, Lee N, Lee S, Lee T and Lee Y M 2008 J. Org. Chem. 73 1379; (i) Abraham E, Brock E A, Candela-Lena J I, Davies S G, Georgiou M, Nicholson R L, Perkins J H, Roberts P M, Russell A J, Sanchez-Fernandez E M, Scott P M, Smith A D and Thomson J E 2008 Org. Biomol. Chem. 6 1665; (j) Park J-J, Lee J H, Li Q, Diaz K, Chang Y-T Chung S-K 2008 Bioorg. Chem. 36 220; (k) Liaveria J, Diaz Y, Matheu M I and Castillon S 2009 Org. Lett. 11 205; (1) Cai Y Ling C-C and Bundle D R 2009 Carbohydr. Res. 3444 2120; (m) Pandey G and Tiwari D K 2009 Tetrahedron Lett. 50 329; (n) Liu Z, Byun H-S and Bittman R 2010 J. Org. Chem. 75 4356; (o) Park J-J, Lee J H, Seo K-C, Bricard G, Venkataswamy M M, Porcelli S A and Chung S-K 2010 Bioorg. Med. Chem. Lett 20 814; (p) Trappeniers M, Chofor R, Aspeslagh S, Li Y, Linclau B, Zajonc D M, Elewaut D and Calenbergh S V 2010 Org. Lett. 12 2928 
21. (a) Liang X, Andersch J and Bols M 2001 J. Chem. Soc., Perkin Trans. 2136; (b) Dondoni A and Perrone D 1997 Synthesis 527; (c) Williams L, Zhang Z, Shao F, Carroll P J and Joullie M M 1996 Tetrahedron 52 11673; (d) Yonezawa Y, Shimizu K, Yoon K-S and Shin C-G 2000 Synthesis 634

22. (a) Kumar I and Rode C V 2007 Tetrahedron: Asymmetry 18 1975; (b) Goff R D, Gao Y, Mattner J, Zhou D, Yin N, Cantu C, Teyton L, Bendelac A and Savage P B 2004 J. Am. Chem. Soc. 126 13602; (c) Azuma H, Tamagaki S, Ogino K 2000 J. Org. Chem. 65 3583; (d) Shirota O, Nakanishi K and Berova N 1999 Tetrahedron 55 13643; (e) Imashiro R, Sakurai O, Yamashita T and Horikawa H 1998 Tetrahedron 54 10657

23. Drewes S E, Khan A A and Rowland K 1993 Synth. Commun. 23183
24. (a) Kumar G, Kaur S and Singh V 2010 Helv. Chim. Acta 94 650; (b) Kumar G, Kaur S and Singh V 2011 ARKIVOC (X) 148

25. (a) Cherest M, Felkin H and Prudent N 1968 Tetrahedron Lett. 18 2199; (b) Ahn N T 1980 Top. Curr. Chem. 88 144; (c) Hoffman R W 1989 Chem. Rev. 891841

26. (a) Cha J K, Christ W J and Kishi Y 1983 Tetrahedron Lett. 24 3943; (b) Chirst W J, Cha J K and Kishi Y 1983 Tetrahedron Lett. 24 3947; (c) Kauppinen P M and Koskinen A M P 1997 Tetrahedron Lett. 38 3103; (d) Chandrasekhar S, Babu B N, Reddy N R and Chandraiah L 2005 Arkivoc (Xi) 40; (e) Yoon H J, Kim Y-W, Lee B K, Lee W K, Kim Y and Ha H-J 2007 Chem. Commun. 79

27. Chun J, He L, Byun H-S and Bittman R $2000 \mathrm{~J}$. Org. Chem. 657634

28. Chung J, Byun H-S, Arthur G and Bittman R 2003 J. Org. Chem. 68355 